\title{
Economic Development Versus Environmental Protection: Executive Oversight and Judicial Review of Wetland Policy
}

I. INTRODUCTION.......................................... 24

II. Judicial Deference Under Chevron ................... 31

III. The Evolution of Section 404 Wetland Policy ...... 36

A. Before the No Net Loss Policy ..................... 37

1. Institutionalized conflict and uncertainty ...... 37

2. Judicial expansion of section 404 jurisdiction . 38

3. Congressional reaction.......................... $\quad 39$

4. Judicial decisions perpetuate institutional conflict......................................... $\quad 39$

5. Inconsistent agency determinations of wetland jurisdiction....................................... 40

B. Going Beyond the No Net Loss Policy............. 41

1. Conflicting interpretations of "no net loss"... 42

2. Agency cooperation fails to resolve conflict .... 43

a. The 1989 federal delineation manual ...... 43

b. The 1989 Corps-EPA memorandum of agreement (MOA) on mitigation........... 44

3. The continuing ambiguity of congressional guidance........................................ 46

4. Displacing agency decisionmaking responsibility ................................. 47

a. Streamlining \& flexibility.................. 48

b. The 1991 federal delineation manual ...... 48

IV. A New Judicial Framework For Deference ........... 50

V. Legislative Responses to the Wetlands Protection Challenge ............................................... 53

A. Disclosure of Regulatory Review Impacts ......... 53 


\section{B. Explicit Section 404 Guidance From From}

Congress ...........................................

VI. Conclusion .......................................... 57

\section{INTRODUCTION}

Landowners and developers typically assume that they can legally proceed with grading and fill activities (for example, levelling property in preparation for subsequent construction or other use) once the necessary state and local permits are obtained. If a project will affect wetlands, ' however, section 404 of the Clean Water Act $(\mathrm{CWA})^{2}$ may require the landowner or developer to obtain further permission from the U.S. Department of the Army's Corp of Engineers (Corps). Persons who violate section 404 can face penalties of up to $\$ 25,000$ per day of violation and one year of imprisonment; the Corps may also order violators to remove all unpermitted fill and any structures built on the fill, and require restoration of the area to its preproject condition at the violator's own expense. ${ }^{3}$ Even those persons experienced in dealing with wetland regulations are caught by surprise with a Corps enforcement order and subsequent penalties. ${ }^{*}$ All landowners, developers, and include:

'The term "wetlands" is defined by the U.S. Army Corps of Engineers to

those areas that are inundated or saturated by surface or ground water at a

frequency and duration sufficient to support, and that under normal circum. stances do support, a prevalence of vegetation typically adapted for life in saturated soil conditions. Wetlands generally include swamps, marshes, bogs, and similar areas.

33 C.F.R. $328.3($ b) (1992). For a discussion of the rationale for regulating development in wetland areas, see infra notes 57.59 and accompanying text.

233 U.S.C. SS 1251-1387 (1991) (amending the Federal Water Pollution Control Act of 1972, Pub. L. No. 92-500, 86 Stat. 816). For a description of $\$ 404$, sec infra part III. Authority to regulate wetlands is also provided by: the Rivers and Harbors Act of 1899 (RHA), 33 U.S.C. $S 403$ and $\$ 407$ (1991); the Marine Pro:ection. Research, and Sanctuaries Act, 33 U.S.C. $\$ 1413$ (1991); and the Fish and Wildlife Coordination Act, 16 U.S.C. $\$ 662$ (1991).

333 U.S.C. $\$$ 1344(s) (1991).

- Consider Bill Ellen, nonprofit wildlife rescue center operator and former environmental engineer, who worked carefully with the Soil Conservation Service and the Corps to secure thirty-eight permits for a project to convert a Maryland estate into a 103-acre wildlife sanctuary. After a new, expansive interpretation of the "wetlands" definition was issued in 1989 (see infra, part III.B.2.a), however, the same Corps 
their legal representatives should therefore monitor the evolving federal regulatory scheme and take steps to ensure accountability for any significant changes. Environmental and community activists committed to the preservation of wetland resources should be equally vigilant.

Existing statutory ambiguity under the $\mathrm{CWA}^{5}$ reflects an enduring conflict between economic development and environmental protecrion. ${ }^{\circ}$ The struggle between these two forces has affected many development projects in Hawai $i$,' and in the nation as a whole. Sometimes landowners become subject to enforcement action because they are unaware that their property contains wetland areas. ${ }^{8}$ Previously exempt prop-

official that Mr. Ellen had been working with ordered all work on the project stopped. The pressure of deadlines under previously-signed subcontracts led 10 "mistakes" and, ultimately, a jail sentence for Mr. Ellen. EPA's Most Wanted, Wall Street Journal. Nov. 18. 1992, at A16. See also The MacNeil/Lehrer News Hour (PBS television broadcast. Jan. 1. 1993) (featuring Bill Ellen's plight).

- See United States v. Riverside Bayview Homes, Inc., 474 U.S. 121, 132 (1985) (noting that Congress did not provide clear guidance under the CWA).

- Oliver A. Houck, More Net Loss of Wetlands: The Amy-EPA Memorandum of Agreement on Witigation Under the $\$ 407$ Program, 20 Envtl. L. REs. 10,212, 10,212 (June 1990). For the direct quote from Mr. Houck on this point, see infra text accompanying note 61.

See, e.g., Christopher Neil, Kailua hills are alive with the sound of discord. Sunday Star-Bulletis \& Advertiser, Jan. 17, 1993, at A27. Neil mentioned the withdrawal of a development proposal by Kaneohe Ranch for the Hamakua Marsh after encountering stiff opposition from Kailua Neighborhood Board members and nearby residents in June 1992, and discussed more recent opposition to a subsequent proposal to build a retirement community and community center on the same site. Id.

A battle over development of the $\mathrm{Ka}^{\prime}$ elepulu wetlands in windward $\mathrm{O}^{\circ} \mathrm{ahu}$, which began in 1978 with a prior landowner, was only recently resolved at substantial cost to the current developer. See Letter from attorney Ronald Y. Amemiya to Honolulu (ity Councilman John Henry Felix (Jan. 13, 1992) (on file with Ronald L. Walker, Wildlife Program Manager for the State of Hawaii Department of Land and Natural Resources). Residents' objections to an application for an after-the-fact Corps permit for the wetland fill resulted in a leveraged settement wherein the developer must spend $\$ 700,000$ to mitigate for lost wetland acreage $\mathbf{\$ 5 0 0 , 0 0 0}$ for habitat creation. and \$200.000 for permanent maintenance). Id. See also Thomas Kaser, Dispuled Enchanted l.ake projecl gets the go-ahead. Honoluzu ADVertiser, Dec. 13, 1991, at Al4.

* In 1986. after the community objected to the start of construction for a house in the vicinity of Kawainui Marsh. the landowner abandoned his plans (which were proceceling in accordance with a valid building permit up to that point) when told that a section 404 permit was also required. Telephone Interview with Donna Kokubun. President. Hawaii Chapter of the National Audubon Society (Nov 20, 1992). 
erties can also fall under the Corps' jurisdiction when a landowner's own activities, or those of third parties (including federal, state, and local government entitites as well as private parties), create artificial wetlands on a particular site. ${ }^{9}$ Even where the presence of wetlands is recognized, however, the regulated community often remains uncertain how to proceed. Unless regulators provide both large and small developers with greater predictability, the current guidelines and standards will continue to deter vital investments.

From the perspective of environmentalists and other activists, on the other hand, wetland regulations can represent a useful tool for thwarting or temporarily stalling controversial projects. ${ }^{10}$ Delays and the added costs of penalties and project modifications have been sufficient, in some cases, to derail otherwise profitable ventures in the past." A

- See Leslie Salt Co. v. United States, 896 F.2d 354 (9th Cir. 1990) (upholding Corps regulation of unintended wetland environments resulting from artificial or even accidental property alterations).

10 Several individuals and groups, including Ho'okahe Wai Ho'oulu 'Aina (HWHA) as caretakers of a kalo lo' $i$ (taro farm) supported by an auwai (irrigation ditch) from Manoa Strearn, objected to plans for the development of a Hawaiian Studies Building on the site because of adverse effects on these associated wetland areas (including pooled water emanating from the nearby $\mathrm{Wa}_{\mathrm{a}}$ ahila culvert). Letter from Michacl $\mathrm{T}$. Lee, Chief of the Corps Operations Division, to Gordon Matsuoka. State Public Works Engineer for the Department of Accounting and General Services (Aug. 17. 1992) (on file with author). Initial statements by the Corps indicated that the filling of all wetlands, including man-made wetlands such as the kalo $10^{\prime} i$, auwai and Wa'ahila ditch, is subject to the Clean Water Act. Id. The Corps issued a cease and desist order two months later, when it discovered that boulders, rocks, soil and grubbed vegetation fell into Manoa Stream as a result of construction activitics. Letter from Michael T. Lee to Gordon Matsuoka (Oct. 16. 1992) (on file with author). The Corps ultimately reversed its initial claim of jurisdiction with respect to the 10 ' $i$ (as insignificant and "relatively recent manmade water features," which are not normally located in fastlands), auwai (also relatively small and constructed on normal!y fastland arcas). and Wa'ahila tributary (because it is "not designated on the Geolngical Survey map as an intermittent stream" and is already culverted for 200 fect upstream from the project). Letter from Lt. Col. James T. Muratsuchi, U.S. Army District Enginecr, to Gordon Matsuoka (Dec. 9, 1992) (on file with author). As of late January, 1993, the project awaits approval of a $\$ 404$ permit for a proposed revetment to prevent further accidental fill of the Manoa Stream. Id.

"For example, environmentalists have staved off a variety of devclopment proposals for Kailua's Kawainui Marsh, the state's largest wetland, including a 400-unit hoissing project and a massive park built on filled land. Kawainui Marsh's fulure io be discussed. Honolulu Star-Bulletin, Sep. 23, 1992, at A5. 
particularly revealing example involves the development of a wetland urea wrst of Kapa'akea Homesteads on the island of Moloka' $i$, which is the subject of ongoing litigation between the Corps and the site's developer. ${ }^{12}$

Conflict, however, is not inevitable under the current regulatory regime. State and federal governments have worked out mitigation plans and set-asides for protected wetland areas in some cases, effectively balancing economic concerns with the conservation of wetland functions and values. ${ }^{13}$ Creative conflict resolution is clearly possible under the currant regulatory system; nonetheless, controversies over wetlands regulation persist because of uncertainty regarding the relative value ascribed to the economy versus the environment.

The friction between economic development and environmental protection received significant attention during the 1992 campaign for President of the United States. The incumbents, President George Bush and Vice President J. Danforth Quayle, sought to characterize their Democratic opponents, Arkansas Governor Bill Clinton and U.S. Senator Al Gore, as radicals planning to protect the environment at the

"See File No. 89-015, witn the Corps' Pacific Operations Division at Fort Shafter. in Hunc'slu. Hawai'i. In an area zoned for housing, the develuper apparenely exercised due diligence ir obtaining necessary county and state permits. for which the appropriate federal agencies were also notified. Id Although a December 1976 Final Finiromenemeal Impact Stateinent prepared for a Mood control project at Kitpatakeal induated the absence of any endangered species, the sighting of a Hawailan stilt by a Corps licle officer led to an enforcement action in 1989 halting the nearly completed project. Id Subsequent offers by the developer to provide mitigation, involving the creation of larger welland areas and paymene of substantial monetary anounts. have been summarily rejected by the United States Fish \& Wildlife Service (USFWS) Id Sir slso File No. 92-006 (concerning litigation over illegal fill activity in the Matunawili weelands on the island of $\mathrm{O}^{\circ} \mathrm{ahu}$ ).

"Plans for the expansion of Azeka's Supermarket in Kihei, Mau: (Kanaha Pond) ran into trouble when the USFWS determined that the property, located near Kathana Pond, seried as a habitat for stilts when vet. Letter from Ernest Kosaka, LSFW'S Field Supervisor, Pacific Islands Office, to l.. Col. Donald T. Wynn. U.S. Army Corps (Apr. 27. 1990) (on file with Ronald L. Walker. Wildlife Program Manager. State of Hawai'i Department of Land and Natural Resources). Subsequent negotiatiens led is a suitable compromise permitring construction while adequatcly protecting valuable wildlife habitat, at a cost of approximately $\$ 470.000$. L.cter from 1.t. (col Donald T. Wynn to Ernest Kosaka (Nov. ?0, 1990) (on file with Ronald l.. Walker. DI.NR). See also supra note 7 (discussing adoption of a mitigation plan for development of the Ka'elepulu wetlands) and infra text accompanying note 58 (listing important wetland functions and values). 
expense of humans." The incumbents themselves were often accused in the media of gutting vital environmental statutes in order to appease big business." In 1991 and 1992, the Bush-Quayle Administration's regulatory review body, the Council on Competitiveness, gained increasing power and prominence as it battled to weaken federal environmental regulations concerning wetlands, hazardous waste, and clean air. ${ }^{10}$

After the 1992 election, the Clinton Administration eliminated the Council on Competitiveness. ${ }^{17}$ Regulatory review under the ClintonGore Administration might have shifted the balance of interests toward environmental protection, ${ }^{18}$ but the administration's fundamental message remained that economic and environmental policies need not be mutually exclusive. ${ }^{19}$ The polarized reactions to the former Comperitiveness Council suggest, however, that the conflict between environmental and economic interests will likely persist. ${ }^{20}$ Public willingness

"See Michael Kranish and Scot Lehigh, Insults $F$ l) as Clinton. Bush Frasel to Kin Stales. Bostos Gloвe. Oct. 30. 1992, at 1. President Bush referred 11. Vie e Pressdentlal candidate Al Gore as "Ozone Man," stating that "|l|his guy is so far ofl in the envirommental extreme, we'll be up to our neck in owls and out of work lor every American. This guy is crazy. He is way out, far out, man." Id

"See. eg. Dianne Dumanoski, Enutronment Nol Gaining Ground Durıng Campaign. Boston Globe, Oct. 4, 1992, at 1

in Id

: Gore lauds abolishment of rule-revieu'ing body, HoNoluhu ADNektisf.k. Jan 23, 1993. at D1 (citing Vice President Al Gore as stating that "an existing review process under the Office of Management and Budget will make sure businesses are not burdened by federal regulations"): see also Eric Pianin and David S. Hilacnrath. Climon to Press Major Deficit Cut; Shart Term Stimulus, Fax Reduchon Fade. Wasissciton Post. Jan 12. 1993. at Al (quoting Leon Panella's assertion, during hearings on his own confirmatisen as Director of the Office of Management and Budget, that Viee President Ciore plans 10 organize a new regulatory review panel).

tn Vice President Gore believes that the United States should utilize "every means ... 10 preserve and nurture our ecological system." Albert Corre. EAstri in Tiir. Balasce (1992) (ciled in Bruce S. Klafter, Businesses Should Head (iore's Hanifesto. SAs Francisco Chronicle, Nov. 30, 1992, at B3).

"Dumanoski, supra note 15. Bill Clinton acknowledged that he had put jobs ahead of the environment as Governor of Arkansas, but also stated that in the process he learned that this is a "false choice" Id.

in The Bush Administration's efforts to balance the conservation ethic with the competing interests of the regulated community were reminiscent of the effort is vindicate prwale property rights under the Regulatory Reform Task Force led by then Vice President Bush. Houck, supra note 6, at n. 10 (citing Exec. Order Nis. 12291. 48 Fed Reg. 21.466 (1983)). 
to accept exccutive influence over regulatory policy-making (also known as executive oversight) has its linits, whether economic development or environmental protection is the motivating factor." Both the proper role of the executive branch in this evolving process and the appropriate standard for judicial review of such issues require careful analysis.

This comment begins by considering the propricty of executive influence on regulatory policy governing wetlands. ${ }^{2:}$ Part II critically examines the mandatory deference model provided by the United States Supreme Court in Cheuron U.S.A., Inc. v. Nalural Resources Defense Council, ${ }^{3}$ and considers the potential application of this model through judicial review of evolving wetlands regulations under section 404 of the Clean Water Act (CWA). This comment argues that despite section 404 's recognized ambiguizies, overly-deferential judicial review is inappropriate, especially where proposed regulatory changes are apparently inconsistent with existing interpretations of the CWA. ${ }^{24}$ Any

" Consider the growth in size and influence of the "Wise Use Cosalition." established io eppose environmental regularions adversely aflecting buman social condfiens-cespecially as related (1) jobs and American competitiveness. As a legislative stalf member to U.S. Sen John Breaux. during the lirst session of the lo2nd Congress. the author observed a concerted lobbuging ellort called the "Fly-in for Freedom." Fishng, logging. homeloulding. and other industries lobbled against environmental protection bills and for a greater atcomedation of ecomomic concerns. Some of the environnental statutes scheduled for reauthorization in 1993. and therefore possibly subject to similar lobbying pressure, include the Clean Water Act, 33 U.S.C. 55 12511387 (1991), the Fishery Conservation and Management Act, 16 U.S.C. 551801 . 1882 (1991), and the Findangered Speces Act. 16 U.S.C. 55 1531-1544 (1991). See

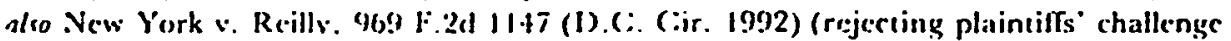
of EPA-issued C:lean Air Act regulations allegedly altered in response to the wishes of the Competitiveness (iouncil)

"Under President Cieorge Bush and Vice President J. Danforth Quayle, the Council on Competitiveness and the White House Domestic Policy Council signilicantly impacted proposals to reformulate wetlands policy under section 404 of the Clean Water Act. Richard S. Sienger. Al.I. H\%T. Kowseonnkestas. Action. Nov.-Dec. 1991. at $12 \cdot 14$.

$\because 467$ U.S. 837 (1984).

* Existing interpretations of the (FWA suggest that the balance of interests under this statule favors encironmental protection over economic development. See United States \& Riverside Bayview Homes. Ine., 47.4 U.S. 121 (1985) (recognizing the breadth of congressional concern for protec uon of water quality and aquatic ecosystems. especially wetlands. and noting their central value in the hydrologic cycle): Smithwick v Alexander. 12 Esirt. L. Rep. 20.432 (4th Cir. 1981) (finding the balance tilting decisively in favor of wellands protection): see also Jeffrey M. Lovely. Comment. Protecting Hietlands. Consideration of Secondary and Social and Economic Effects by the United 
agency decision-making process that merely reacts to the views of the executive branch lacks independence and effectively violates democratic principles of accountability. Part III reviews the historical evolution of section 404 in order to support Part II's conclusions regarding statutory ambiguity, accountability, and independence. Subparts $A$ and $B$ of Part III cover the periods before and after introduction of the "no net loss" policy for wetlands. The no net loss policy appeared, initially, to umify competing wetland perspectives. ${ }^{25}$ Later, the phrase simply highlighted a fundamental conflict between developers and conservationists that is enshrined in the statute. ${ }^{2 n}$

After laying these foundations, this comment curns to the task of offering recommendations to ensure accountability for future agency decisions. Part IV echoes the suggestion of Northwestern University School of Law Professor Thomas Merrill that courts should review regulatory changes through precedent-based judicial deference to the executive branch." Professor Merrill's "executive precedent" model

States Amy Corps of Engineers in its Wellands Permilting Process, 17 B.C. ENvrt. Arr I. REv. 647, 677-78 (1990) (stating that the (WWA was "enacted to protert the natural environnent," not 10 deride between the economic interests of alcernative sites as a matter of public policy) (citing Mall Propertics, Inc. v. Marsh, 672 F. Supp. 561, 573 (D.Mass. 1987)). Contra Hoffman Homes, Inc. v. Environmental Protection Agency: 961 F.2d 1310 (7th Cir.), vacaled to facilitate settlement negotsations, 975 F.2d 1774 (7th Cir. 1992), cited infra notes $54-55$ and accompanying text; see also infra nute 49 for an interpretation of the CWA suggesting that the phrase "unacceptable adverse impacts" at 33 U.S.C. \$ $1344(c)$ arguably indicates Congress" willingness to accept some adverse wetland impacts. for example, when the balance of interests fators eronomic development.

Other statutes demonstrate that Congress knows how to give economic interests higher priority than environmental protection. or at least an equally balanced consideration. See infro notes 45 (highlighting a statutory provision designed to prevent economic disruption or unemployment), 46 (cataloging environmental statutes that pay greater attention to economic interests by calling for cost-benefit analyses). 91 (noting that some environmental protection statutes simply establish long (erm goals), and 92 (listing environmental protection statutes that require a balanced consideration of economic interests).

"See infra note 84 (citing the National Wetlands Policy Forum as the genesis for a consensus strategy on the regulation of wetlands).

in See infra part III.B I

*. See generally Thomas W. Merrill, Judicial Deference to Executive Precedent, 101 Yale L. J. 969 (1992). Professor Merrill's expertise in this area comes from his 1987 to 1990 service as Deputy Solicitor General, Department of Justice. when he argued or helped brief a large number of U.S. Supreme Court cases involving the "Cheuron doctrine." Id. at 969. 
achieves many of Cheuron's regulatory-efficiency goals, but refuses to sanction executive influence unchecked by meaningful judicial review. Part $V$ provides two more immediate remedies. First, subpart A recommends legislation requiring the disclosure of an agency's rationale for succumbing to executive oversight. Then, subpart $B$ draws upon analogous criticisms of Clean Air Act $(\mathrm{CAA})^{28}$ developments in order to encourage explicit clarification of Congress's intent. Congressional reauthorization or amendment could provide a viable opportunity to replace the ever-shifting political rhetoric between economic and environmental concerns with a more stable, harmonious regime.

\section{Judicial Deference Under Chevron}

In enacting the CWA, Congress sought to provide uniform water quality protection to a broad scope of areas with inherently different functions and values. ${ }^{29}$ Unfortunately, the original legislative drafters lacked the scientific knowledge necessary to determine appropriate standards. The resulting delegation of authority was necessarily ambig. uous. ${ }^{30}$ Before the United States Supreme Court's decision in Cheuron U.S.A., Inc. v. Natural Resources Defense Council," courts generally applied "discretionary deference" (based on an arbitrary and capricious standard of review) to agency interpretations of ambiguous laws. ${ }^{32}$ After

s* Air Pollution Prevention and Control Act, 42 U.S.C. SS 7401-7671q (1991).

- Federal Water Pollution Control Act, Pub. L. No. 92-500, 86 Stat. 816 (codified at 33 U.S.C. 1251-1387 (1991)).

"Merrill, supra note 27, at 997 (noting that similarly ambiguous delegations are found in many other statutes establishing jurisdictional or boundary limitations). See also Solid State Circuits v. U.S. Environmental Protection Agency, 812 F.2d 383 (8th Cir. 1987) (discussing alleged violations of constitutional duc process presented by the inability to weigh, in advance, the probable validity or applicability of a CERCLA clcan-up order, given that the statute imposes treble liability for failing to comply with a valid order). In Solid Stale Circuits, the Coun of Appeals for the Eighth Circuit characterized the Comprehensive Environmental Response, Compensation, and Lia. bility Act (CERCLA, or Superfund), 42 U.S.C. SS $9601-9675$ (1988), as "in some circumstances ... silent or ambiguous." Id. at 392.

" 467 U.S. 837 (1984) (holding that the EPA's interpretation of the term "stationary source," as permitting polluting-facility owners to treat all emitting devices as if they were under a single "bubble," represented a valid construction of the Clean Air Act).

"Cf. Motor Vehicle Manufacturers Assn. v. State Farm Mutual Auto. Ins. Co., 463 U.S. 29 (1983) (applying a "hard look" standard to hold that a decision by the Secretary of Transportation. rescinding a passive automobile restraint requirement, was arbitrary and capricious because it was not supported by a reasoned analysis). 
Cheoron, however, the courts can apply "pure deference" to these interpretations when Congressional direction is imprecise. The pure deference standard effectively precludes full judicial consideration of the substantive issues associated with policy disputes." For example, the ambiguity inherent in section 404 could theoretically prevent the judiciary from determining whether expansive exccutive oversich unduly influences agency decisions. ${ }^{3+}$

In Cheoron, the United States Supreme Court acknowledged that agencies "may within the limits of [congressional] delegation, properly rely upon an incumbent administration's vietvs of wise policy" to inform its judgments. ${ }^{35}$ Where Congress has "directly spoken to the precise question at issue," the Court will adopt and enforce that answer; if the statute is ambiguous, however, judicial review shifts into a pure deference mode, which permits agencies to "lill the gap" with any reasonable construction of the statute. "In effect. "administrative actors become the primary interpreters of federal statutes and pcourts are] relegate[d] to the largely inert role of enforcing unambiguous statutory terms." '":

Professor Merrill criticizes the Court's expressed rationale for adopting a restrictive, deferential framework in Checron. The Court justilies deference to the executive branch by invoking democratic principles of accountahility. ${ }^{38}$ Merrill suggests, on the other hand. that this expli-

"Merrill. supra note 27. at 1002 farguing that contesmal laciss. such as the degree of the agency's expertise and the existence of refiance interew mulicated by: the agency's interpretation. are ignored by the courss

"See generally id. (noting that Chetron can be read io require mandatory delerence to agency interpretations where Congress proveled antuguous statum gundancel. ver also infra notes 35-37 and accompanying text.

" 467 U.S. at 865-66. The disputed issue in Chei ron could be seen as part of the deregulatory thrust of the early Reagan Administration Merrill. supra note 26. at 975. see also Chevron, 467 U.S. at 857-59. In response to the wishes of the Reagan Administration, the EPA “interpreted the term 'statunarv source in the (:lean Atr Act to permit owners of polluting facilities to treat all emating alenes as if the wete under a single 'bubble.' thereby minimizing the costs of (1)mplying with the emissions standards ${ }^{\circ}$ established by the Art. Id at 975-if (cuing $467 \mathrm{C} S$ at $8+11$ ) The (anurt of Appeals for the District of Columbia Circuit invaludated the F.P.A interpretatun. in a prior stage of the litigation. largely becausc it was contrary io prior precedent Merrill, supra note 26, at 989.

Id. at $8+2-45$.

* Merrill, supra note 27 . at 969-70.

see id at 978-79 (suggesting that the Court viewed " ageney decisionmaking [as] always more democratic than judicial decisionmaieing because all agences are atcountable... to the President (who is elected by the people)") 
cation is based upon a "fictitious delegation" of legislative power from Congress to executive agencies." According to Merrill, this "dubious fiction . . . threatens to undermine / the functional theory of separation of powers, ] the principal constitutional constraint on agency misbehavior." Cheuron effectively permits agencies not only to make policy within the limits of their organic statutes, but also to define these limits."

Despite Cheuron's apparent holding that an implementing agency may change regulations simply by articulating a rational basis for its decision, courts should assume (unless Congress expressly provides to the contrary) that Congress expects agencies to apply their experience and expertise when reformulating regulatory policy. The secrecy inherent in the executive oversight process, however, often produces incomplete adninistrative records and furthers hidden agendas. The courts should not, therefore, use Cheuron to validate rulemaking that is no more than a response to political choices.":

Admittedly, the challenged regulatory about-face by the Environmental Protection Agency (EPA) in Chevron took place pursuant to a new philosophy introduced by President Ronald Reagan." The Court expressly determined, however, that the EPA's decision was a "rea-" sonable accommodation of manifestly competing interests. " +4 The Court noted, in addition, that Congress "sought to accommodate the conflict between the economic interest in permitting capital improvements to continue and the environmental interest in improving air quality. "4s Correspondingly, the courts could logically extend this reasoning to

“ Id. at 1014 .

"Id at 998: ser also id at 994.

- Id. al 997 .

- Sef Margarel Gilhooley, Executive Oversight of Administrative Rulemaking: Disclosing the impact. 25 IVI. I. R F. 299, 303 (1991). Consider .New York v. Reilly. 969 F.2d 1147 (D.C. Cir. 1992), in which the Court of Appeals for the District of Columbia Circuit rejected the allegation that the EPA improperly relied upon the views of the Comperitiveness Counril when it abandoned proposed rules under the Clean Air Act. The court held that the E:PA's decision to omit materials separation requirements (designed in control industrial emissions) was adequately supported by the administraive record Reilly. 969 F.2d at $11+9-51$. The agency based its decision on uncertainty over associated costs, as identified through testimony by the U.S. Conference of Mayors . Vational Resource Recovery Association. It

"Cherron, 167 U.S. at 857.59.

" Id. at 865 .

"Id at 851 The Clean Air Act contains a provision entited "Mcasures to prevent economic disruption or unemployment." 42 il.S.C. $\$ 7425$ (1991) (emphasis added). 
support increased consideration of economic factors in the regulation of wetlands. A careful consideration of the language, policies, and history of the CWA, however, suggests that Congress intended broader protection of water quality than air quality. Whereas other environmental protection statutes pay significant attention to cost-benefit analyses, ${ }^{46}$ reflecting Congress' intent to accept certain risks to human safety and environmental degradation, an equivalent commitment to balancing economic and ecological concerns is not readily apparent in the CWA. ${ }^{+7}$

Potential judicial analysis of section 404 policy decisions is complicated, however, by the ambiguity generally associated with wetlands regulation. Proponents of President Bush's Wetland Protectior: Plan ${ }^{\text {th }}$ could argue that Congress did not intend the CWA as a full wetland protection measure; in other words, the Act was designed only to protect those ecosystems that serve important water quality functions." ${ }^{40}$

in See, e.g., the Federal Insecticide, Fungicide and Rodenticide Act, 7 U.S.C. I5 136-136y (1991) (accepting, implicitly, that environmenta) and other harms associatcd with pesticides are outweighed by their beneficial uses); Coastal Zone Management Act. 16 U.S.C. $51454(b)(7)(1991)$ (balancing ecological, cultural, historic and esthetic values as well as needs for economic development): National Environmental Policy Act, 42 U.S.C. $4331(\mathrm{~b})(5)$ (1991) (recognizing the government's responsibility io achieve a balance between population and resource use which will permit high standards of living and a wide sharing of life's amenities); id. \& 4332 (1991) (recognizing. indirectly, the need to consider economic and technical factors when analyzing impacts on the human environment); Solid Waste Disposal Act (as amended by the Resource Conservation and Recovery Act), 42 U.S.C. S 6901(a)(2) (1991) (recognizing that economic and population growth needs require increased industrial production).

"Compare supra note 24 and infra part III.A.1 (discussing the congressional compromise between economic and environmental concerns under the Clean Water Act. in other words, bifurcating administrative authority under both the Corps and EPA) with supra notes 45.46 and infra notes $91-92$ (noting that statutory guidance concerning the appropriate balance between these competing interests under the CWA is not as specific as other statutory references, including cost-benefit analyses and other balancing tests). A possible explanation for this difference is that Congress acted upon a perceived need for broader protection against human impacts on water resources, as opposed to impacts on the air.

" Fact Sheet from the White House Office of the Press Secretary, Protecting America's Wellands (Aug. 9. 1991) (on file with the aurhor) (hereinafter President Bush's Wetlands Plan].

- See Clean Water Act, 33 U.S.C. $\int 1344$ (c) (1991). The Administrator of the EPA is authorized to veto any permit issued by the Corps for the discharge of dredged or fill material:

whenever he determines, after notice and opportunity for public hearings, that 
Advocates for this proposition might draw support from the United States Supreme Court's decision in Uniled Stales v. Riverside Bayview Homes, ${ }^{30}$ which noted that section 404 provides ambiguous guidance. ${ }^{51}$ Given a hypothetical decision by the EPA to increase the scope of allowable adverse impacts on wetlands, ${ }^{52}$ therefore, the Riverside decision could serve as precedent for judicial deference, à la Cheuron, to this new interpretation of the CWA's statutory mandate. Under Cheuron, a restrictive EPA interpretation of the CWA would apparently be entitled to deference. ${ }^{33}$ The decision by the Court of Appeals for the Seventh Circuit in Hoffman Homes, Inc. v. Environmental Prolection Agencyst lends additional support to claims for limited section 404 application. The Seventh Circuit interpreted Riverside restrictively to support its holding that the CWA does not either explicitly, or through delegation of Congress' constitutional power to regulate interstate commerce (under Article I, Section 8 of the Constitution), authorize regulation of all wetland resources." 5

the discharge of such materials into such area will have an unacceplable adcerse effect on municipal water supplies, shellish beds and fisher) areas (including spawning and breeding areas), wildlife, or recreational areas.

Id. (emphasis added). The phrase "unacceptable adverse effect" could be interpreted as an indication of Congress" willingness to accept some adverse wetlands impacts, notwithstanding the CWA's general commitment to environmental protection. See also 40 C.F.R. S 231.2(c) (1991) (codifying the EPA's veto authority through regulations covering any adverse impact resulting in the significant loss of, or damage to. wildlif: habitat).

$\$ 474$ U.S. 121 (1985).

"Id. at 132.

"President Bush arguably sought to implement this decision in his Wetlands Protection Plan, supra note 48. See also infra subpart lll.B.4 (discussing the growing tide of economic conservativism in the United States, and the corresponding desire for an interpretation of section 404 that provides greater consideration of economic interests).

"See, e.g. New York v. Reilly, 969 F.2d 1147 (D.C. Cir. 1992) (rejecting plaintiffs' allegation that the EPA improperly relied upon the vietvs of the Comperitiveness Council when it abandoned proposed rules under the Clean Air Act).

" 961 F.2d 1310 (7th Cir. 1992) (invalidating EPA's regulation defining waters of the United States to include isolated wetlands). On Sept. 4, 1992, this decision was vacated upon grant of rehearing, 10 facilitate settlement negotiations. Hofman Homes Inc. v. Environmental Prolection Agency (Holfman Homes II), 975 F.2d 1774 (7th Cir. 1992).

"Hoffman Homes, 961 F.2d at 1311, 1320 (finding that isolated intrastatc wetlands are excluded from federal regulation, and potential use of such wetlands by migratory birds is insufficient to invoke federal regulatory authority): of. Leslic Salt Co. $x$. United 
Overly-deferential analysis under Cheuron, however, constitutes little more than a rubber stamp for otherwise questionable administrative procedures. Agencies adopting any regulatory changes pursuant 10 executive oversight should support these changes with detailed explanations of their rationale for succumbing to outside views. Regardless of the merits associated with the Bush Administration's attempt to inject greater balance in section 404, the process that generated President Bush's Wetlands Plan remains disconcerting for two reasons: (1) influence was applied behind closed doors, not in public hearings; and (2) increased attention to economic concerns is apparently inconsistent with existing statutory interpretations of section $404 . .^{\text {ib }}$ Given the high stakes of the wetlands debate, and the potential for continued polarization of the environmental and ecomomic constituencies, administrative efforts to modify existing wetland regulations should avoid the appearance of impropriety that surrounded the Competitiveness Council. Attempts to harmonize environmental and economic interests under the Clean Water Act must adhere (o) democratic principles of accountability and be immune from undue inlluence.

\section{The Evolution of Section 404 Wetland Policy}

Part 11, above, argued that broad judicial deference with respect to changes in wetland regulations is inappropriate, despite statutory ambiguity, because of deeply-ingrained democratic values related to independence and accountability under our system of government. A review of section 404's historical development provides a better understanding of the underlying inconsistencies associated with wetlands regulation. This part also illustrates the fact that executive oversight can change regulatory policy without sufficient public accountability.

In the past, most people viewed wetlands as wastelands, a home to mosquitos, ooze, and pestilence, that were to be "diked, drained, and filled in for housing developments and inclusirial complexes, converted

States. 896 F.2d 354 (9th Cir. 1990) (upholding the U.S. Army Corps of Engineers' regulatory jurisdiction over man-made wetlands and wetland areas having the potential to serve as migratory bird habitat).

* Compare supra notes 24 and 46 (indicaling (i) a broad concern by Congress for water quality protection, especially with respect w wetlands. (ii) a rejection of costbenefit balancing under the CWA. as compared to other environmental statutes which require such analysis, and (iii) that the balance of interests will. in any event, tilt decisively in favor of ivetland protection.) wuth supra note 45 and infra notes $91-92$ (listing statutes that employ cost-benefit analyses and wher flexible approaches to the conservation and management of resources in an effort 10 balance economic and environmental impacts cquitably). 
to farmland, [or] used as receptacles for household and hazardous waste." 37 Eventually, heightened awareness revealed wetlands as sensitive transitional areas with subtle intrinsic values, serving vital environmental functions such as ground water recharge; flood and sediment control; prevention of shoreline erosion and saltwater intrusion; wildlife habitat formation; water quality maintenance; enhancement of biological productivity; and provision of recreational opportunities. ${ }^{38}$

Despite numerous benefits furnished by wetlands and continuing losses of such areas, however, federal wetland initiatives do not provide comprehensive protection for this vital natural resource. For example, high value wetlands are lost every year because activities such as draining, excavating and channelizing are not regulated. ${ }^{59}$ Section 404 , which requires permits for the placement of dredge and fill material in the waters of the United States, is the most important federal regulatory program for wetland protection. The ambiguous Congressional guidance provided in this legislation, however, allows a divisive conflict to persist.

\section{A. Before the No Net Loss Policy}

Despite progressive regulatory revisions, and almost twenty years of litigation, section 404's competing constituencies, i.e. developers and conservationists, remain polarized as the nation's wetland resources continue to dissipate. A bifurcated administrative structure under section 404, divided between the U.S. Army Corps of Engineers (Corps) and the EPA, ${ }^{\text {;0 }}$ provides:

a recipe for endless conflict between those who would protect what is the United States' most productive and endangered ecosystem-its wetlands-and those who would exercise their most fundamental economic righi-to develop the land they own. ${ }^{61}$

\section{Institutionalized conflict and uncertainty}

Congress awarded administration of the section 404 permit program to the Corps, based on that agency's previous experience with permit

"Barbara Sleeper, Wellands, Wonderlands, ANimals, Jan.-Feb. 1991, at 12. See also Steven L. Dickerson. The Evoloing Federal Welland Program, 44 Sw. L. J. 1473, 1474 (1991).

m. Sleeper, supra note 57, at 12-13; Dickerson, supra note 57, at 1474-75.

"Dickerson, supra note 57, at 1496.

as See infra par III.A.1.

"Houck, supra note 6, at 10,212 (emphasis added). 
programs in navigable waters. ${ }^{62}$ In addition, the EPA can veto any Corps permit that would "adversely affect municipal water supplies, shellfish beds, and fishery areas . . . , wildlife, or recreational areas." 63 This bifurcated structure reflects Congress' compromise between the values of economic well-being (the Corps' primary mission) and environmental protection (the EPA's mission). ${ }^{64}$

The resulting procedural uncertainty is accompanied by substantive ambiguity; section 404 does not clearly define its jurisdictional limits. The statute merely authorizes Corps permits for placement of dredge and fill material in the "waters of the United States." 65 Wetlands are neither defined nor specifically addressed in the CWA; the Act's goal is simply "to restore and maintain the chemical, physical, and biological integrity of the Nation's waters." 60

\section{Judicial expansion of section 404 jurisdiction}

Initially, the Corps limited its scope of authority under section 404 to traditional navigable waters. ${ }^{67}$ Public interest environmental groups, however, sought greater ecosystem protection. In the landmark decision National Resources Defense Council v. Callaway, ${ }^{68}$ fulfilled the environmental community's hopes. As a result, the term "navigable waters" under the CWA now encompasses all waters of the United States within the reach of the Commerce Clause.

a: See. e g., Rivers and Harbors Act of 1899 (RHA), 33 U.S.C. S\$ 403, 407 (1991); Fish and W'ildlife Coordination Act, as amended 1965, 16 U.S.C. 662 (1991): and Marine Protection. Research, and Sanctuaries Act of 1972, 33 U.S.C. S 1413 (1991).

"' Shannon J. Kilgore. Comment, EPA's Role in Wellands Protection, Elaboration in Bersani ". U.S. EPA, 18 ENVTL. L. REP. 10,479, 10,481 n. 16 and accompanying text (Nov. 1988) (citing S. Rep. No. 1236, 92nd Cong.. 2d Sess. 141.42 (1972)).

it Id. at 10,480. But see Benjamin H. Grumbles \& Kenneth J. Kopocis, Water Resources Acts- Deteloping an Environmental Corps, 21 ENvtL. L. Rep. 10,308 (June 1991). The Water Resources Development Act of 1990, Pub. L. No. 101-640, 104 Stat. \$604. established environmental protection as a primary mission for the Corps. Id. at 10.309. 10.314-21. The Wetlands Research Program established by the Corps also indicates increased environmental sensitivity in this agency. See U.S. ARMY ENGINeER Waternays Experiment Station, The Wetlands Research Procram (1991) (brochure on file with author).

" 33 U.S.C. 5 1362(7) (1991).

$\sim 33$ U.S.C. S 1251(a) (1991).

^ 33 C.F.R. 55 209-210(d)(1) (1974).

^ 392 F. Supp. 685 (D.D.C. 1975). 
The Corps' regulatory jurisdiction applies to interstate waters (including wetlands), waters affecting interstate or foreign commerce, tributaries thereof, and wetlands adjacent thereto. ${ }^{69}$ The crucial element in defining Corps jurisdiction is whether or not a particular saturated area (wetland) is hydrologically connected to a navigable water of the United States. After promulgation of the Callaway decision, supporters of the Corps' prior, more limited application of section 404 sought 10 reinstate the old interpretation through congressional amendment.

\section{Congressional reaction}

In 1977, Congress rejected efforts to limit the jurisdictional scope of section 404 to traditionally navigable waterways and their adjacent wellands." Although the House of Representatives passed such a limiting measure," the Senate defeated a parallel amendment. ${ }^{27}$ The debate centered on wetland preservation issues."

Proponents of limited jurisdiction argued that the inclusion of nonnavigable waters far exceeded congressional intent; opponents asserted that a narrower definition would exclude vast stretches of crucial wetlands to the detriment of wetland ecosystems, water quality, and the aquatic environment generally. ${ }^{7+}$ The statute, however, exempted certain agricultural, forestry, ranching and other operations." In spitc of these clarifications, section 404 still causes uncertainty and confusion.

\section{Judicial perpeluation of institutional conflict}

The judiciary finally reviewed the bifurcated decisionmaking authority created under section 404 in Bersani $v$. Robichaud. ${ }^{26}$ The holding by

"See supra note 1 for the Corps' current definition of wetlands.

i" See generally H.R. Conf. REP. No. 95-830, 95th Cong., Ist Sess. 10-11 (1977). reprinted in 1977 U.S.C.C.A.N. 4326, 4424, 4475-80.

"United States v. Riverside Bayview Homes, Inc., 474 U.S. 121, 136 (1985) (citing H.R. 3199. 95th Cong.. I st Sess., S 16 (1977)).

$\because$ Riverside Baytiew. 474 U.S. at 136 (citing S. 1952, 95th Cong., Ist Sess., 5 49(b) (1977)).

- 123 Conc. Rec. H10,426-36, S26.710-29 (1977). ciled in Riverside Bayuiew. 474

U.S. at 136 .

$\because$ Id.

$\because$ Dickerson, supra note 57, at 1478 (citing 33 U.S.C. $1344(\cap(1)(A)(1988)$ ). But sec $\$ 1344(f)(2)$ (prohibiting recapturc, or new uses, that affect the reach or circulation of weilands).

- 850 F.2d 36 (2d Cir. 1988), cert. denied, 489 U.S. 1089 (1989). 
the Court of Appeals for the Second Circuit failed, however, to clarify the law. Although Bersani implicitly approved EPA's "practicable alternatives" test" over the Corps' "public interest review" test, ${ }^{78}$ the Court of Appeals for the Second Circuit found only that EPA's interpretation was reasonable. ${ }^{79}$ The court expressly declined to rule that EPA's position was entitled to deference. ${ }^{\text {no }}$

According to one commentator,

[t $\mid$ his system of permit review is duplicative, cumbersome and inconsistent. The Corps is given the task of serving two masters, while it lacks the tools to fully satisfy either one. Consequently, the Corps' permitting process often times produces unsatisfactory and inconsistent results."

This conclusion is reinforced by observations that the judiciary has yet to provide reliable guidance for the Corps, remanding section 404 permit decisions both for considering and for failing to consider economic factors. ${ }^{\text {B2 }}$

\section{Inconsistent agency determinations of welland jurisdiction}

A final example of the uncertainty which existed prior to the "no net loss" standard is revealed by the divergent agency perspectives on how 10 identify wetlands for jurisdictional purposes. The identification of wetlands is also referred to as delineation, or defining the scope of authority under section 404. The original Corps and EPA delineation manuals were both based on a multipararneter approach. ${ }^{\text {A3 }}$ The manuals

"Bersani, 850 F.2d at 39. The court determined that the Corps must, during is permit review process, avoid the development of wetland areas if possible, by first considering the economic feasibility of alternative sites regardless of ownership. Id.

In Id. at 39-40. The court balanced the benefits of a proposed developmentincluding economic considerations and the right to reasonable private use-against potential dsmage to wetland resources, in order to secure both adequatc protection and reasonable utilization of environmental resources. Id.

$\because$ Id. at 46.

mo Id. at 45 (noting that the cour was "not thoroughly persuaded that FPA's interpretation was entitled to deference"); see also Kilgorc, supre note 63, at 10.487. 88.

" Dickerson, supra note 57, at 1486.

". See, e.g. Lovcly, supra note 24, at 668, 673-78 (citing Mall Properties. Inc. v. Marsh. 672 F.Supp. 561 (D.Mass. 1987), appeal dismissed. 841 F.2d 440 (1st Cir.), cert. denied, 488 U.S. 848 (1988); Sierra Club v. Marsh, 769 F.2d 868 (1st Cir. 1985); Hough v. Marsh, 557 F.Supp. 74 (D.Mass. 1982)).

n1 Thomas A. Sands, Comparison of 1987 Corps Wetland Delineation Manual and the 1989 Federal Manual for Identifying and Delineating Wellands (1991) (unpublished manuscript on file with the author). According to this paper. Mr. Sands was principal author of the original U.S. Army Corps of Engincers' Wetland Delineation Manual. ReCocnizing, WetLands (1987). Id. at 1. 
emphasized that all three of the following technical criteria must be met for an area to qualify as a wetland: wetland vegetation, hydric soils and hydrology. ${ }^{94}$ Again, the crucial element justifying jurisdiction was the hydrologic link to, and potential adverse effect upon, navigable waters of the United States.

Evaluation of the wetland indicators mentiened above involves highly complex processes. Different interpretations led to inconsistent applications by field personnel for the respective federal agencies with wetland responsibilities: the Corps, EPA, Fish \& Wildlife Service, and the Department of Agriculture's Soil Conservation Service. The Fish \& Wilkdife Service applied a significantly different basis for wetland juris.lietion than the other agencies; its 1979 manual required only one of the three wetlan'f criteria." This inconsistency severely impeded efforts to regulate ivetlands uniformly $y^{\mathrm{R}}$ and, predictably, heightened tensions between competing inter'st groups. After fifteen years of continuing conflict and uncertainty, the regulated community marshalled its resources in an effort to revitalize wetland regulation. As Section B explains below, the resulting proposal for resolving regulatory conflicts merely highlighted a fundamental difference of perspective concerning the proper scope of wetland regulation.

\section{E. Going Beyond the No Net Loss Poticy}

Current elements of the ongoing regulatory controversy are traceable to the aftermath of a compromise that, ironically, appeared to unify previously irreconcilable wetland perspectives. In 1987, a prestigious group of state governors, business and environmental leaders, academicians and developers came together at the National Wetlands Policy

"Id. at 1. The term "hydric soil" refers to soil that is "finoded, ponded, and/or sitturatrd long enough during the growing season to produce anacrobic conditions in the upper pare" of the soil prufils. Id. at 5. The term "hydrology" refers to "|a|reas that are inundated or have saturated soils for at least a week during the growing season more often than cvery other year un the average." Id. at 7. See also Dickerson. supra note 57, at 1482-83.

"Sands, supra note 83. at 1. See also Dickerson, supra note 55, at 1482-83 (citing Fisil and Wilinitie Service, U.S. Dept. of the Interior, FWS/OBS-79/31, Classifiliation of Wethands and DeEpivater Habitats of the United States (1979)). The Fish \& Wildlif: Service's 1979 Delineation Manual simply requires one of the three iriteria-periodic wetland vegetation, predominantly hydric soil, or saturation-it serne time during the growing scason. Sands, supra note 83, at 3.

N Dickerson, supra nnte 55, at 1483. 
Forum to recommend a consensus strategy for protecting the nation's wetlands. ${ }^{87}$

In 1988, President George Bush elevated the importance of wetlands protection by adopting the Forum's fundamental goal, no net loss of wetlands. The optimism surrounding the no net loss policy soon dissipated, however. The fragile consensus was torn apart by the following developments: promulgation of a revised wetland delineation manual, ${ }^{\text {s }}$ EPA's veto of a permit for the popular Two Forks Dam public works project, ${ }^{89}$ and mounting controversy over the proper role of mitigation within the permit process. ${ }^{90}$ This part of the article demonstrates how the underlying conflict enshrined in section 404 led to a deterioration of the no net loss consensus. Finally, subpart B closes with the observation that unaccountable agency action concerning regulatory policy, whether due to executive influence or overzealous implementation by the Corps or the EPA, is an abuse of basic democratic principles.

\section{Conflicting interpretations of "no net loss"}

The conflict between economic and ecological interests under section 404 nared once again shortly after the 1987 National Wetland Forum's vague no net loss compromise. Rather than interpreting no net loss as a fexible long term goal," environmentalists pushed for pure protection of wetlands. They urged litcral, immediate, and comprehensive application of the CWA to prevent the loss of any wetlands. Landowners

"The Conservation folindation, Protectinc america's Wetlands: An Action Acristia, the Final. Report of the National Wetlands Policy Forum fhercinafles Furcs Report: Lovely, supra note 24 , at 648 n.7.

- See discussion infra at subpart III.B.2.a.

* Section 404 Program Critics Coll for Reform, LANd LetTER (W.J. Chandler \& Assoc) |hercinafter Chandler], Mar. 1, 1991, ar 1.

- See discussion infra at subpart III.B.2.b.

"Long-term goals in certain statutes indicate Congress" desire for a fexible approach to pressing environmental problems where carefully-tailored solurions are currently unavailable, or unwise. The MMPA expresses a long term goal of "insignificant dolphin mortality rates approaching zero" for fishing activities involving the setting of purse-seine nets to catch yellowfin tuna (the nets are intentionally set on clolphins, which are often found swimming above schools of yellow-fin tuna). Marine M1-mmal Protection Act (M.MPA). 16 U.S.C. S 1372 (1991). Similarly, the CWA establisnes an unachievable. industry-forcing "goal" of eliminating pollutant discharge by 1985. Clcan Water Act, 33 U.S.C. $51251(a)(1)$ (1991). 
and developers, on the other hand, sought balanced consideration of both economic and ecological factors in section 404 permit decisions. ${ }^{22}$

\section{Agency cooperation fails to resolve the conflict}

The four principal federal agencies with wetlands responsibilities (the Corps, the EPA, the Fish \& Wildlife Service, and the Department of Agriculture's Soil Conservation Service) appeared to reach a consensus on these issues in 1989. Conflicts along the way, however, soon revealed that the debate over wetland regulation was far from settled. The environmental community complained that the agencies' efforts were falling short, and the business community countered that the agencies' agreement represented "a drastic change from the past."

(a) The 1989 federal delineation manual.

Complaints about inconsistent application of wetland identification:

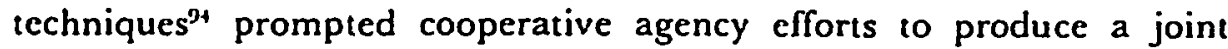
delineation manual. In January 1989, the four agencies agreed to use the same mandatory definition for identifying wetlands. ${ }^{95}$ The agencies implemented this new manual without providing for public review and comment, claiming that "the agreement does not change the way wetlands are defined." 96

' 2 The Endangered Species Act calls for consideration of both the cconomic impact caused by proposed critical habitat designation, 16 U.S.C. $51533(\mathrm{~b})(2)$, and the benefits provided by alecrnatives consistent with the statutory goals, Id. $\$ 1536(\mathrm{~h})(1)(\mathrm{A})$ (1991). The Fishery Conservation and Management Act promotes fisheries utilization that provides the greatest overall benr.it to the nation, while taking into account and allowing for regional variations in the resource. 16 U.S.C. \$ 1801-1882 (1991).

"Marianne Lavelle, Wellands: the new battle ory in Washington, NAT'L L. J.. July 23, 1990, at 24.

"Dickerson, supra note 57, at 1483-84.

"s Se generally U.S. Army Corps of Engineers, U.S. Environmental Protection Agency, U.S. Fish and Wildlife Service, U.S.D.A. Soll Conservation Service, Federal Maniual for Identifyinc and Delineating Jurisdictional. Wetlands (1988) [hereinafter Federal. Delineation Manual]. The Federai. Delineation Manual was not formally adopted uniti 1989. The predecessors of the Federal Delinention Manual are discussed supra in subpart III.A.5. See also Mensorandum of Agreenent between the Army and EPA Concernisg the Determination of the Geographic Jurisdiction of the Section 404 Program (Jan. 19, 1989).

- Chandler. supra note 89. at 1. 
Journalists reported that "[i]n 1988 the U.S. Fish and Wildlife Service (USFWS) estimated 100 million acres of wetlands in the continental United States; in 1990, after adoption of the manual, it produced virtually the same estimate." ${ }^{97}$ Although technically correct, these reports failed to point out that the USFWS's interpretation did not concur with generally recognized assessments of wetland acreage under the Corps/EPA 1987 Delineation Manual. Misleading and in. flammatory statements like this failed to consider the dramatic changes made by the new manual. For example,

the approximately 7,000 vegetation species used as wetlands indicators also occur with some frequency in non-welland areas, .. . | (the 1989 manual] creates thirteen special conditions under which land may be deemed wetland by satisfying only one or two of the three required technical criteria, ... [and the 1989 manual] is replete with technical faws including the failure to recognize significant regional differences in vegelation and soil across the country..$^{98}$

\section{(b) The Corps-EPA memorandum of agreement on wetlands miligation.}

Another document illustrating the agencies' efforts to cooperate is the Memorandum of Agreement (MOA) on Wetlands Mitigation between the Corps and the EPA. Prior to this arrangement, the Corps and the EPA disagreed about the validity of mitigation as a consideration during section 404 permitting decisions. In Bersani v. Robichaud, ${ }^{19}$ the Court of Appeals for the Second Circuit did not address or even acknowledge EPA's general policy that mitigation is not an appropriate means of satisfying the section 404(b)(1) guidelines. The court's holding, however, appeared to favor the EPA's interpretation. ${ }^{100}$

Subsequent consultations between the two agencies led to a revised MOA on Wetlands Mitigation incorporating the EPA's sequencing

"Tim Searchinger and Douglas Rader, The Condominium Crowd Makes its Move on Wellands, L.A. DAlty J., Aug. 21, 1991, at 6. The 1989 Manual apparently incorporated FWS's perspective of wetland indicators. See supra subpart III.A.5.

* Dickerson, suprn note 57, at 1484 (emphasis added).

- 850 F.2d 36 (2d Cir. 1988), cert. denied, 489 U.S. 1089 (1989).

100 Id. at 46; see also Houck, supra note 6, at 10,212 (noting that with time, Bersani "might have caused the Corps to cease mitigation-based permitting," however, developments in the Wetlands Forum "subsumed the issue"). 
approach. ${ }^{\text {U1 }}$ The agencies also committed themselves to no net loss by requiring tha. "[wetlands] mitigation should provide, at a minimum, one for one functional replacement (i.e., no net loss of values)." "w2 Although the MOA was originally issued on November 15, 1989, the White House delayed actual implementation of the agreement several times in order 10 respond to criticisms submitted by the Departments of Energy and Transportation, the oil and gas industry, and Alaskan development interests. ${ }^{103}$ As a result, the revised MOA on Wetlands Mitigation allows the Corps to deviate from the otherwise required sequencing approach whenever EPA agrees that a proposed discharge into wetlands is "necessary to avoid environmental harm," will produce "environmental gain or insignificant environmental losses," or whenever the "mitigation measures necessary to meet this goal are mut feasible, not practicable" or inconsequential. ${ }^{104}$ Reactions to these MOA amendments epitomize the divergence of views concerning section $+(1) 4$

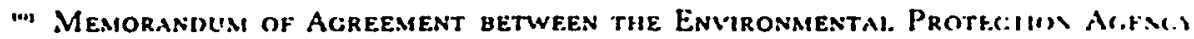

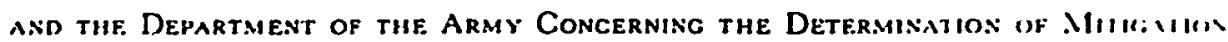

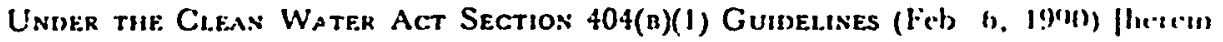
atiet MOA on Wettands Miticintion], at 2, 3. The EPA considers wheilues amuned discharge should be permitted by applying a sequential procedure (avoielanc.. Imm gation, and compensation), granting a permit only where the agency determines- lirst. that potential wetland impacts have been avoided to the maximum extent practicable. second, that remaining unavoidable impacts will be mitigated to the extent appropriate. and practicable; and finally, that the permit applicant will compensate for aquatit resource values losi or damaged. Id. at 3; see also 40 C.F.R. $\$ 230.10$ (1992) (corlitịne the EPA's sequencing approach).

-It is important to recognize that there are circumstances where the impacts of a project are so significant that even if alternatives are not available, the discharge may not be permuted regardless of the compensatory mitigation proposed." MOA ON IVethanos Mitticintion, supta, al 3 n.5 (citing 40 C.F.R. $\$ 230.10$ (c)).

10: Id. at 5. In other words, the WOA defines "no net loss" as meaning that any loss of wetlands must be replaced, either through creation, restoration or modification. with wetlands of at least furctionally equivalent value. See also William L. Wiant, 7he Army-EPA Agreement on t'ellands Mitigation, 20 ENvTl. L. ReP. 10,209, 10.210 (June $199(1)$.

"' Want, supra note 102, at 10.210-11; Royal C. Gardner, The Army-EPA Mitigation Agrecment: No Retrat From IVetlands Protection, 20 Envtl. L. Rf.p. 10.337, 10.337 nn 1.5 (Aug. 1990).

im MOA on Wfillaxd Mitication, supro notc 101, at 2. 3; Want, supra notc 102 , at 10,210 (noting also that the MOA recognizes that no net loss of wetlands functions and values "may not be achieved in each and every permit action"); Gardner. supra note 103, at 10,341 . 
that continues to polarize conservationists and developers. ${ }^{105}$ Although the revised MOA may solve some of the problems associated with section 404, it "does not represent the FUNDAMENTAL RESTRUCTURING [of wetlands regulation] that is necessary." 106

\section{The continuing ambiguity of congressional guidance}

Congress is fully aware of the public uncertainty concerning the relationsi ip between economic and environmental factors under section 404. It is also clear that section 404 does not provide comprehensive protection of the nation's wetlands. Our elected representatives continue, however, to address wetlands loss in a piecemeal, inconsistent fashion. ${ }^{107}$

During the 102nd Congress, staff members of the Senate Environment \& Public Works Committee suggested that the Committee would not include any significant changes to the section 404 program in its 1992 reauthorization bill. ${ }^{108}$ The National Wetlands Coalition and other

ins See id. at 10,211; Ronald A. Zumbrun, Walland Preservation Rule Adopted Without Public Comment, L.A. DAlly J., May 1, 1991, at 6; Houck, supra note 6. at 10,214.

106 Dickerson, supra note 57, at 1488 (emphasis added). A uniform wetland evaluation technique would represent a significant step toward improved regulation of wetland areas.

${ }^{107}$ See, e.g., the Conservation Easements on Wetlands in FmHA Inventory Property Act of 1990, 7 U.S.C. S 1985(g) (1991); the Farms for the Future Act of 1990, 7 U.S.C. 4201 (note) (1991); the Fish and Wildlife Coordination Act, as amended 1965, 16 U.S.C. $\$ 662$ (1991); the Migratory Bird Conservation Fund, as amended 1966. 16 U.S.C. S 715k (1991); the Wetlands Loan Act, as amended 1988, 16 U.S.C. $5715 k-3$ (1991); the Watershed Protection and Flood Prevention Acl, as amended 1990, 16 U.S.C. IS 1001.09 (1991); the Water Bank Program (WBP), as amended 1980, 16 U.S.C. SS 1301-11 (1991); the Erodible Lands and Wetland Conservation and Reserve Program, 16 U.S.C. SS 3801-39d (1991); the Emergency Wetland Resources Act, as amended 1989, 16 U.S.C. SS $3901-32$ (1991); the Coastal Wctlands Planning. Protection and Restoration Act of 1990, 16 U.S.C. S5 $3951-56$ (1991): the North American Wetlands Conservation Act of 1989, 16 U.S.C. $554401-13$ (1991): (the Land and Water Conservation Fund), 16 U.S.C. SS 460 through 460l-22 (1991): and the Marine Protection. Research, and Sanctuaries Act of 1972, 33 U.S.C. 1413 (1991).

Chandler, supra note 89, at 6. See also The Status of Wellands Science: hearing before the Subcommittee on Environmental Protection of the Commitec on Environment \& Public Works. S. Hrg. No. 102-69, 102nd Cong., 1st Sess. 1-2 (statement by Senator Max Baucus of Montana), 24 (statement by Senator John Chafee of Rhode Island) (April 9, 1991): Inplementation of Section 404 of the Clean Water Act: hearing before the Subcommitter on Environmental Protection of the Committee on Environment \& Public Works. S. Hrg. No. 102. 
interested parties then lobbied members of Congress who were not on the committee. Their vigorous efforts resulted in the introduction of several bills aiming to reform wetlands regulation. ${ }^{109}$

\section{Displacing agency decisionmaking responsibility}

A growing tide of economic conservatism ${ }^{10}$ appeared to convince President George Bush to take preemptive action despite the introduction of these bills. On August 9, 1991, the Bush Administration unveiled a new plan for protecting the nation's wetlands." The effort suggested a return to the vindication of private property rights, previously initiated in 1981 through a Regulatory Reform Task Force led by then-Vice President George Bush. ${ }^{12}$ President Bush's Wetlands Protection Plan apparently sought to rein in section 404 by injecting more balance into the permitting process. ${ }^{13}$ The potential impact of this plan recognizably diminished with the departure of President Bush and the election of Bill Clinton. Without more explicit congressional guidance, however, section 404's fundamental inconsistencies, conflicts between environmentalists and developers, and further wetland losses,

450, 102nd Cong., 1st Sess. 172 (letter from the National Governor's Association urging no changes to section 404 until amendments to the 1989 delineation manual have been given an opportunity to improve the program) (June 20, July 10, and Nov. 22, 1991).

tis H.R. 1330, 102nd Cong., 1st Sess. (sponsored by Rep. Jimmy Haycs, D-La.); S. 1463, 102nd Cong., Ist Sess. (sponsored by Sen. John Breaux, D-La.). Other bills introduced that same session also sought 10 revise $\$ 404$, including: H.R. 251, 102nd Cong., 1st Sess. (sponsored by Rep. Charles Bennet, D-Fla.); H.R. 404, 102nd Cong., Ist Sess. (sponsored by Rep. John Hammerschmidi, R-Ark.); and H.R. 2400. 102nd Cong., 1st Sess. (sponsored by Rep. Lindsay Thomas, D-Ga.). . No substantive action was taken on any of these bills.

"n Sec, e.g. Michael Satchell, Any Color But Green, U.S. News \& World Report. Oct. 21. 1991, at 74 (reporting that the "wise use" coalition blames poor economic conditions on environmental statutes, which do not sufficiently balance nonenvironmental interests).

:1 See generally President Bush's Wetlands Plan, supra note 48.

ii: See Exec. Order No. 12,291, 48 Fed. Reg. 21,466 (1983) (implementing a policy based on the belief that American businesses are too heavily regulated by the federal government).

"The Presideni's Plan was apparenlly prepared to resolve a controversy between regulatory amendments proposed by the Competitiveness Council. See generally supra part I, and note 15. See also infra subpart IIl.B.4.b (discussing the scientific recommendations of the Federal Interagency Committee for Wetland Delineation). 
are likely to persist. ${ }^{14}$ A quick evaluation of President Bush's Wetlands Plan provides a sense of the business community's interests concerning wetland regulation and reveals several problems associated with unchecked executive oversight.

\section{(a) Streamlining $\mathcal{E}^{2}$ flexibility.}

President Bush's plan attempted to streamline section 404 procedures and introduce greater flexibility in analyzing proposed developments. The President sought to replace consulting agency appeals of individual permits granted lyy the Corps with appeals based on resources or issues of national significance. "11 The President's interpretation of section 404 under the plan placed increased emphasis on balancing economic and ecological interests. 16 In addition, the plan provided incentives for private restoration or creation of wetlands, including a system of granting mitigation-banking credits where the effects of proposed developments in wetlands areas are mitigated through off-site enhancement projects. ${ }^{117}$

\section{(b) The 1991 federal delineation manual.}

The President's plan also sought to revise the Federal Delineation Manual. Pursuant to the Bush Administration's wishes, the EPA promulgated proposed revisions to the Federal Delincation Manual for public comment on August 14, 1991:18 One of the criteria for delineation, wetlands hydrology, requires inundation for fifteen or morc consecutive days, or saturation for twenty-one or more consecutive days. " As a result, some areas designated as wellands under the 1989 delineation manual were not wetlands under the revised manual. ${ }^{230}$ The

1. Houck, supra note 6, at 10,212 nn. 8-13. Houck commented that "|t/he actors ind alliances may change .. . but the basic positions rcmain the same-intratctableand proceeding from entirely different assumptions." Id, at 10,212.

': Sec President Bush's Wetlands Plan, supra note 48, at 4.

un /d. at 4-5. The President's plan resurrected the Corps' balancing icst. which was implicitly rejected by Bersani in favor of the EPA's sequencing approach. See supra parı III.A 5 (discussing the respective tests).

"See, e.g., Robert W. Hahn and Robert N. Stavins, Incentiue-Based Eni"ronmental Regulation: $A$ New Era from an Old Idea?, 18 Ecoloci L. Q. 1 (1991).

:* 56 Fed. Reg. 40,446-40,480 (Augusi 14, 1991).

a." Id.

$\therefore$ Robcrt T. Stewart and Chris M. Amantea. President's New Policy Shyfts Focus. NAT L L. J.. Feb 10, 1992, at 27. Only arcas cxperiencing seren days of saturation within eighteen inches of the ground surface are designatcd as wetlands. Id 
agencies continued to assert, however, that they did not change their wetland definitions. ${ }^{121}$

Executive attention can, and sometimes does, contribute to the development of sound national policy. Where this oversight displaces agency decisionmaking authority, however, executive inlluence risks conflict with the president's constitutional responsibility to ensure that the laws are faithfully executed. ${ }^{122}$ A collision between conservation and business interests apparently led to political tradeoffs and subsequent changes in wetland delineation rules. ${ }^{123}$ Soon after this collision, several scientists quit the Federal Interagency Committec for Wetland Delincation in a dramatic protest of undue administrative influence. ${ }^{\prime: 1}$ The "infusion of politics into what was initially designed as a techntal exercise" 125 prompted the following individuals to make statements critical of the Bush Administration: William Sipple, Chief Ecologist EPA Office of Wetlands, stated that he would have engaged in "unethical behavior" by agreeing to the proposed changes withou! first getling public comment; EPA ecologist Charles Rhodes, Jr., complained of "external pressures" and the redrafting of technical provisions by "others with limited wetlands experience"; and finally, Acting FllS Director Bruce Blanchard sent a letter to EPA refusing to accept its fourteen-day inundation threshold because it was "confusing and $110 \mathrm{~h}$ nically indefensible." "12s

Whether or not the compromises implemented by the Comperitileness Council would have actually improved the status quo, democratic principles require adherence to the statutory mandate provided under section 404 of the CWA. Typically, Congress intends agencics 10 alpply.

Id at 36 (citing 56 Fed. Reg. 65,963 (Dec. 19. 1991). which seeks io portrat the proposed addition of a new wetlands regulatory section as a simple descripticun es new identifying characteristics for wetlands).

$\because:$ See Gilhooley, supra notc 42, at 311.

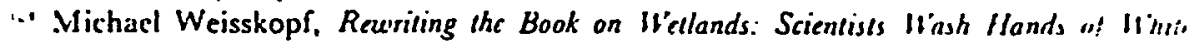
House's Definition of Prolecied Areas, Wishisctos Post, May 3, 19!1. .11 A2.3. Kinl, Sichneider. 3 Li.S Agencies Want to Loosen Wielland Curbs: Draft Propoval Kricul kifs i. Ginernment. New York Tises, May 15, 1991. al A18. See also Gilhnoley, supon nuse 12. at 311-13 nn. 76-90 (discussing Gilhooley"s view that the exceutive oversight process pernits manipulation of agency analysis to fit a predetermined outcome)

1:* Weisskopl, supra note 123 (indicating that these scientists quit after political innsiclerations reflecting the interests of the business and development communu overrode their scientific recommendations).

- Id (emphasis added).

- Id 
their expertise rather than simply respond to political choices. When the President's advisors became deadlocked over the "extent of protection to be conferred on the nation's dwindling wetlands," however, they chose to pull the President into the politically sticky issue rather than rely on technical expertise. ${ }^{127}$ Even if a plan like President Bush's were viable, that fact wo.ild not justify immunity from effective judicial review.

\section{A New Judicial Framework for Deference}

With a firm grasp of the regulatory evolution of wetlands protection under section 404 well in hand, it is now appropriate to return to this article's primary concern: the influence of executive oversight on the rulemaking process. Professor Thomas Merrill theorizes that Cheuron U.S.A., Inc. v. Nalural Resources Defense Council'2B has not had the revolutionary impact on judicial review that many commentators assume. ${ }^{129}$ Cases applying Cheoron "have on the whole produced fewer affirmances" than those that do not follow Cheuron. ${ }^{130}$ Furthermore, the United States Supreme Court itself often ignores Cheuron in cases involving deference questions." The Court's apparent reluctance to

12: Michacl Weisskopf, Bush: Arbiter on W'ellands Dispule?. Washiscton Post. July 30, 1991, at A13. Weisskopf reported unidentified sources as stating that President Bush was to receive an options paper "asking him to sort out rechnical matters normally left to his advisers. such as the number of days a parcel of land must be inundated to qualify as a wetland." Id. According to Weisskopf. "EPA Administrator Reilly was outnumbered [at a meeting of the Council on Competitiveness] by officials seeking to weaken wetlands safeguards beyond what he ha|d] proposed." Id.

ish 467 U.S. 837 (1984).

130 Merrill, supra note 27, at 970. Contra Pcter H. Schuck \& E. Donald Elliot. To the Cheuron Station: An Empirical Study of Federal Administrative Law. 1990 Duke L.J. 984.

su" Merrill, supra note 27, at 984.

i" See, e.g.. National Labor Relations Board v. Curtin Matheson Scientific, Inc.. 494 U.S. 775 (1990)(holding that a NLR B rulc is entitled to considerable deference so long as it is rational and consistent with the organic statute. even where the rule represents a departure from the Board's prior policy): Marsh x. Oregon Natural Resources Council, 490 U.S. 360 (1989) (holding that a decision by the Corps to issue a Supplemental Information Report, rather than a second supplemental EIS, in order to review new information affecting a dam project, is entitled to deference provided the agency has made a reasoned decision based on its analysis of those documents): Equal Employment Opportunity Commission v. Commercial Office Prods. Co.. 486 U.S. 107 (1988) (holding that EEOC's interpretation of the Civil Rights Act, as permitting immediate EEOC jurisdiction over C.jvil Rights Act violations prior to 
apply Cheuron is probably linked to that case's apparent all-or-nothing approach. If congressional limits are discernible, the Court exercises purely independent judgment with no consideration of the executive viewpoint; otherwise, the Court gives maximum deference to the executive branch. ${ }^{132}$

Indiscriminate application of Cheoron can be said to reflect the continuing rivalry between mandatory and discretionary deference models in the judicial branch. ${ }^{133}$ As with many aspects of public policy, truth, justice, and equity probably lie somewhere in the middle of these two extremes. Professor Merrill suggests a potentially viable solution that assimilates the judicial deference doctrine into the general juridical practice of following precedent. ${ }^{134}$ Under Merrill's executive precedent model, the courts are asked to follow precedent generated by a different branch of government. ${ }^{135}$ The courts' decision to defer would "entail a three-part inquiry: (1) Is there an executive precedent? (2) How strong is that precedent? (3) Given the strength of the precedent, does an independent judicial examination of statutory interpretation compel a different result?" 136 Under this model, the courts would affirm agency decisions that present a combination of strong precedent and congruence with congressional intent, and reject those that present a combination of weak precedent and tension with congressional intent. ${ }^{137}$

Professor Merrill's model makes sense because executive interpretations of law are analogous to decisions by courts of coordinate jurisdiction. ${ }^{138}$ Executive interpretations "share much in common with judicial precedent."'139 For example, strengths and weaknesses exist on

expiration of the statutorily required 60 days after termination of State agency proceedings, is entitled to deference where reasonable). There are numerous other cases involving deference questions where the Court has apparently ignored Cheoron. See Merrill, supra note 27, at 982 and Appendix.

"' Merrill, supra note 27, at 977.

iss Id. at 1032.

is" Id. at 1003-31.

i' Id. at 1003-12.

inn Id. at 1010.

"Id. at 1014. Application of this model to recent wetland proposals or to the carlier stages of $S 404$ implementation is a useful exercisc, but is beyond the scope of this comment.

in Id. at 1004 .

iso Id. 
both sides of the ledger when comparing courts and agencies. The characteristics of technical expertise, familiarity, and accountability, for example, favor the agencies. The courts, on the other hand, benefit from legal expertise, freedom from time constraints, and insulation from political pressure. Professor Merrill's executive precedent model encourages deference to the judgments of more accountable political actors, but avoids the practical and theoretical failings caused by Cheuron's all-or-nothing approach. ${ }^{140}$ Whereas the Court's current practice of tempering Cheuron with ad hoc exceptions lacks internal coherence, ${ }^{1+1}$ the executive precedent model "strikes a more enduring balance between executive, legislative, and judicial perspectives, and between the forces of change and stability."

Many features of the discretionary deference doctrine, which were apparently banished under Cheuran, "suddenly become explicable once we view the practice of deference as at form of following precedent." $1+3$ Under the executive precedent model, the discretionary deference doctrine's traditional contextual factors- express delegations, agency expertise, longstanding interpretations, well-reasoned decisions, the existence or lack of interagency agreement, contemporaneous interpretations, congressionally-ratified interpretations, the level of statutory ambiguity and independent judicial judgment-are all weighed against each other on a sliding scale. ${ }^{14}$ Although Professor Merrill's suggested model "may be complex . . . it is not unprincipled." "Th' The model encourages the courts to provide more revealing, candid reasons for either deferring to or invalidating agency decisions. ${ }^{\text {tho }}$ According to Professor Merrill,

there are too many different types of circumstances, including different statutes, different kinds of application, different substantive regulatory or administrative problems, and different legal postures in which cases arrive, to allow 'proper' judicial attitudes about questions of law 10 be reduced to any single simple verbal formula. ${ }^{4 ;}$

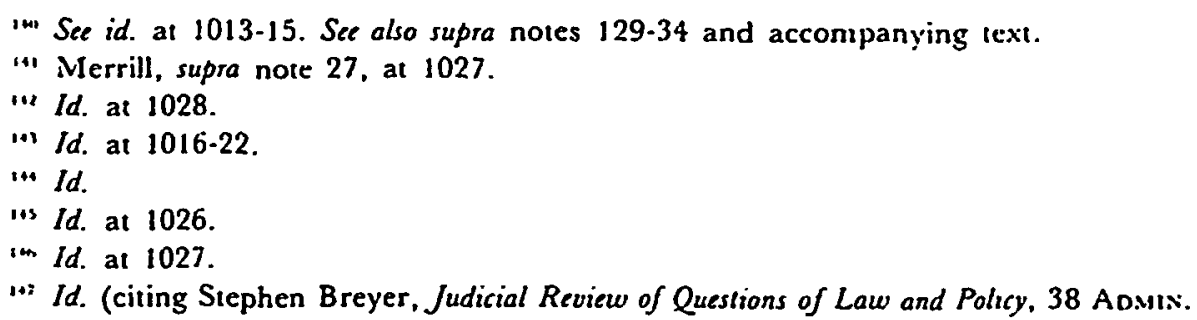
L. REv. 363, 373 (1989) (criticizing mandatory judicial deference as an improper standard of review)). 


\section{Legislative Responses to the Wetlands Protection Challenge}

Legislative action may be more effective than the judicial reform proposed by Professor Merrill, supra part IV, especially given the continuing threat to wetlands posed by concern over American competitiveness and economic growth. The length of time and cost involved in mounting effective legal challenges, not to mention the politically charged atmosphere, also support congressional action in favor of judicial reform. If development interests ultimately persuade Congress to incorporate more balance into section 404 , the legislative branch could adopt or acquiesce in modifications such as those included in former President Bush's Wetlands Plan. ${ }^{148}$ Until that time, however, any effort to limit the protection of wetlands under section 404 will necessarily conflict with long-standing interpretations of the CWA. ${ }^{149}$

\section{A. Disclosure of Regulalory Review Impacts}

The infusion of politics into the regulatory review process through executive oversight arguably displaces an agency's obligation to make independent regulatory decisions based on its experience and expertise. The veil protecting the processes of executive oversight could, however, deflect even a "hard look" "130 by the courts into the legitimacy of such action. This problem can be addressed by requiring the disclosure of

'"w Senators John Chafee (R-RT) and Max Baucus (D-MT) cautioned FWS Director John Turner that "revisions to the manual should not be used to effect policy changes" in $S 404$, and that if "you believe that changes are needed, we ask that you submit such recommendations to the Congress for its consideration." Letter from Chafee and Baucus to Tumer, cited in Johnson, Administration altempts to bend wellands science. THE LEADER, June 1991, at 1.

ios See supra notes 24 and 46 for a discussion of greater congressional concern for environmental protection under the Clean Water Act, as compared to other environmental statutes. But see supra notes 49,54-55 and accompanying text for an argument to the contrary. Suggesting, respectively, that Congress implicitly acknowledged some ivetland resources are not subject to regulation, or that the legislative branch cannot rely on its consitutional power under the commerce slause to extend regulatory jurisdiction over all wetland resources. Id.

1\% In Motor Vehicle Manufacturers Assn. v. State Farm Mutual Auto. Ins. Co., 463 U.S. 29 (1983), the United States Supreme Court applied a "hard look" standard to reject, as arbitary and capricious, a decision by the Secretary of Transportation rescinding passive automobile restraint regulations because the decision was not supported by a reasoned analysis. 
administrative policy as it affects agency decisionmaking. ${ }^{131}$ This proposal will not reveal the give-and-take of executive and agency communications in reaching a decision. Instead,

agencies would designate, as both an administration and agency position. any policy adopted to reflect specific oral or written comments of $O M B$ [the Office of Management and Budget] or the Whitc House made during the regulatory review process ... the agency would also identify its initial position as a policy alternative it considered and provide reasons for adopling a different position. ${ }^{\text {s? }}$

For example, under this proposal the regulatory record for the 1991 Federal Delineation Manual would have to include EPA's carlier proposal for broader wetland protection as a rejected alternative." The agency would also have to explain why a more limited definition was adopted instead of its earlier proposal. According to Environmental Defense Fund biologist Douglas Rader, the fifteen and twenty-one day definitions proposed in former President Bush's now-abandoned Plan "were pulled out of the air," and have "no bearing on ecological reality." "1s4

Disclosure is not aimed at insulating agencies from politically responsive influence. It is meant, rather, to reinforce the agencies' ultimate responsibility to ensure that adoption of an administration position is consistent with the agency's statutory mission. ${ }^{\text {s' }}$ Disclosure

"See generally Gilhooley, supra note 42, at 320-21. See also id. at $307 \mathrm{nn}$. 48-55, 335 nn. 189-92 (criticizing the latk of documentation in the public record concerning the Competitiveness Council's role in the alteration of a proposed EPA rule). Iegislation to require disclosure of extra-agency influence was intreduced during the 2 nd Session of the 102nd Congress. See S. 1942, 137 Cosc. Rec. S16.250 (Nov. 7, 1991) (the Regulatory Review Sunshine Act). For earlier examples, see 128 Covs. Rrc. 5285 . 305 (1982) (S. 1080, the Regulatory Reform ACl of 1982) and 132 Cosc. Kec. 572. 574 (1986) (S. 2023 proposing establishment of a public file disclosing any intervention by the Office of Management and Budget into the rule-making process). The latter example is also discussed at 128 CoNc. REc. 25,662-63 (1982) and in Oversight of O.MB Regulatory Review and Planning Process: Hearings before the Subcomm. on Intergovernmental Relations of the Senale Comm. on Gou't Affairs, 99th Cong., 2d Sess 56.98 (1986).

"Gilhnoley, supra nore 42, at 301-02 (emphasis added).

is See supra part III.B.4 for discussion of the exccutive oversight process, and the intervention of President Bush, as displacing the EPA's statutorily-mandated decisionmaking authority.

11. Stenger, supra note 22, at 12-14.

is Gilhoolcy, supra note 42 , at 303 . 
will provide greater accountability in the regulatory process, and give courts the information they need to accurately assess compliance with congressional mandates. ${ }^{156}$ Professor Margaret Gilhooley, of Scton Hall Law School, confidently dismisses concern that this disclosure requirement may represent an inappropriate intrusion into the deliberative process. ${ }^{137}$ Although " $[$ l] influencing agency decisions," its influence "cannot exceed the statutorily delegated responsibility of the agency." 158

\section{B. Explicit Section 404 Policy Guidance from Congress}

When first enacted, the CWA provided a "new shape for administrative process-one that would avoid the use of expertise as an excuse to inaction and would protect agencies from capture by special intercsts." "iss The initial evolution of section 404 under CWA's broader policies ${ }^{150}$ generally conformed to this procedural design, but developments in recent years suggest that additional legislative guidance is now required.

In his examination of comparable Clean Air Act (CAA) ${ }^{\text {tist }}$ developments, Bruce Ackerman. Professor of Law at Yale University, notes that EPA's failure to make sensible regulatory policy was a sympton of organizational breakdown under the Act. ${ }^{162}$ This failure was caused in part by vague formulas for environmental protection that too readily delegated basic value choices to agency expr.rts. Although Congress

is Id. at nn. 19-20 and accompanying text (citing Verkuil, Welcome to the Constantl) Evolving Field of Administrative Law, 42 ADMIN. L. REv. 1, 2 (1990)).

"Gilhooley, supra note 42, at 350. See also id. at 335-48 nn. 193-24i (noting that such intrusions are vtherwise prohibited by executive privilege).

in Id. at 350. See also Chevron, 467 U.S. at 865 . "[A]n agency to which Congress has delegated policymaking responsibilities may, within the limits of that delegation. properly rely upon the incumbent administration's views of wise policy to inform its judgments" provided that accountability to the people is preserved. Id. (emphasis added).

130 Bruce A. Ackerman \& William T. Hassler, Ciena Conldirty Air (1981). at 1 (discussing general characteristics of th.e evolving administrative process in the context of the Clean Air Act).

in See supra subparts III.A.1 through 5.

ini 42 U.S.C. SS $7401-7671 \mathrm{lq}$ (1992).

is: Ackerman, supra noce 159, at 2, 124. 
accorded high. priority to scrubbing technology, ${ }^{163}$ the agencies could have selected other more ecologically sensible and less costly mechan.isms for combatting air pollution instead. ${ }^{164}$ In effect, an extraneous interest in applying uniform standards rather than accounting for regional differences subverted the CAA's goal of reducing total air pollution. ${ }^{163}$ If Congress had given more explicit guidance on economic and environmental values, this result might have been avoided.

Professor Ackerman advises that "it is imperative ... that /Congress'] early efforts in agency-forcing be replaced by statutory schemes that promise a more fruitful dialogue between politicians and technocrats in the decade[s] ahead." 166 Admittedly, the political compromises that weakened the CAA are different from the proposals for limiting federal wetlands jurisdiction: "|u|nlike many other environmental laws that require a facility or project to attain a certain level of pollution control, wetlands regulation simply determines whether the project will be built in the first place. "isi Persons interested in convincing Congress to reform section 404 of the CWA can rely upon the lessons provided by Professor Ackerman. Although the CWA represents an initially successful utilization of agency-forcing provisions, breakdowns in communication between politicians and agency scientists threaten to exacerbate the statutory conflict between economic and environenental concerns.

Congressional statements of purpose and explicit statutory goals will not necessarily provide precise solutions, but could help the experts resolve internal conflicts. ${ }^{14}$ The pursuit of congressionally-formulated

10) A technique called "flue gas desulfurization" that reduces the amount of sullur dioxide particles releised into the air as a by-product of industrial production; the process involves a device attached to smokestacks which evokes a chemiral reation attracting sulfur dioxide into a lime solution that is sprityed in the path of exhaust gases-which is later removed, dewatered and extruded in the form of sludge. Ackerman, supra note 159, at 15-16.

iss See generally Dale W. Jorgensen \& Yeler J. Wilcoxen, Environenental Regulation and Economic Growth, 21 RaNd J. Econ., 314 (1990).

10s Ackerman, supra note 159, at 45-47; see also Bruce $A$. Ackcrman and William T. Hassler, Beyond the New Deal: Coal and the Clean Air Act, 89 Yale L. J. 1466, 1492 96 (1980) (hereinalier Beyond the New Deal).

is Ackerman, supra note 159, at 4 (emphasis added); see also Beyond the New Deal, supra note 164, at 1470.

167 William L. Want, Expanding Wetlands Jurisdiction Affects Property Transactions. N^t'ו. L. J., Nov. 13, 1989, at 19. See also supra note 149.

in See, e.g. Grumbles \& Kopocis, supra note 64; John Wicbster Kilborn, Purchaset 
wetland protection policy takes the lessons of the CAA to heart and applies them to the CWA. To paraphrase Professor Ackerman, Congress must be careful not to mix clean water symbols with the economic self-interest of landowners in a way that invites cynicism about self government. ${ }^{169}$ Acquiescence to wetlands regulatory changes like those proposed by former President Bush, a plan that might resurface in subsequent political debates, is tantamount to acting against Professor Ackerman's advice. Whether Congress wishes to clarify its original intention by (a) requiring balanced consideration of economic and environmental interests under the Clean Water Act or (b) expressly prohibiting the agencies from making such comparisons, our elected representatives should take affirmative action. The policy implications inherent in such a choice should be debated and resolved on the floors of the U.S. House of Represenatives and the U.S. Senate, not behind the closed doors of an executive oversight committee meeting, especially if dramatic changes of policy will receive a mere rubber-stamp of approval from the judiciary.

\section{Conclusion}

Divergent interpretations of the phrase "no net loss" (a long term goal in the minds of developers; a more immediate mandate for conscrvationists) reflect the basic policy conflict inherent in section 404 of the Clean Water Act. Advocates for the retrenchment of existing wetland protection policies have legitimate concerns; their focus on the impacts of environmental statutes on local and national economies understandably promotes grass-roots and institutional support for regulatory reform. Environmental regulations have had an undeniable impact on local economic development efforts. ${ }^{370}$ Whether or not the current regulatory regime adequately balances economic development with environmental protection is, therefore, a worthwhile topic for debate. The concerns motivati $\cdot g$ passage of the Clean Water Act in the first place, however, have not dissipated. In fact, improved under-

Liability for the Restoration of Illegally Filled Wetlands under Section 404 of the Clean Wiater Act. 18 Eivvt' L Afr. 319 (1991): William K. McGrcciey, Note, A Public Availability Approach to Section 40\%(b)(1) Allernatives Analysis: A Practical Definition for Practicable Alletnatives. 59 Geo. WaSh. L. Rev. 379 (1991).

15.) See ACKersian, supra note 159, at 116 (referring to clean air symbols); see also Bojond the Neu Deal, supra note 164, at 1566.

$\therefore$ See supra notes $7-13$ and accompanying text. 
standing of the impacts of human activity on the environment, and continuing losses of vital resources, counsel against retrenchment of existing statutory environmental protections. In either case, we must resolve the apparent tension between these interests in order to ensure the rational conservation and management of national and local wetlands. Any changes to the process should, however, take place in a way that respects democratic principles of accountability.

Expanded executive oversight and broadened judicial deference enabled President Bush's administration to attack longstanding statutory interpretations of the CWA regarding environmental protection."1 Although President Clinton eliminated the Competitiveness Council., ${ }^{12}$ these twin forces of change could resurface. Agency supervision is one of the president's constitutionally-approved executive functions, but agencies also have a legal responsibility to exercise independent judgment. Broad, deferential judicial review of executive influence, under Cheuron U.S.A., Inc. v. Natural Resources Defense Council, ${ }^{\text {i3 }}$ deprives the public of an essential tool for checking alleged excesses in the executive branch. ${ }^{174}$ As discussed in Section IV above, the courts should be ready to undertake meaningful judicial review of executive influence, especially where regulatory changes merely reflect responses to political pressure. The public interest is best served when democratic principles of accountability are upheld.

Professor Merrill's executive precedent model encourages judicial deference based on traditional contextual factors. ${ }^{135}$ Agency expertise, longstanding statutory interpretations, well-reasoned decisions, the ex-

"Compare supra notes 24 (discussing present judicial interpretations of the Cll'A as favoring environmental protection) and 46 (regarding the distinction between Congress' ambiguous, compromise bifurcation of $\$ 404$ administrative authority under the E.PA and the Corps, and other environmental statutes) with supro notes 45 (cataloging statutorily authorized cost-benefit analysis policies under the Federal Insecticide. Fungicide and Rodenticide Act, the National Environmental Policy Act, and the Resource Conservation and Recovery Act), 91 (noting flexible long term approaches to the resolution of environment-development problems under the Marine Mammal Protection Act and the National Pollutant Discharge Elimination System) and 92 (listing statutorily: authorized balancing of environmental and cconomic factors under the Endangered Species Act and the Fisheries Conservation and Management Act).

"isee supra note 17.

1" 467 U.S. 837 (1984); see supra part II for discussion on the potential application of this case in a challenge to changes in the wetland regulatory scheme.

1" The Council on Competitiveness also influenced the development of clean air. recycling and hazardous waste policy. Stenger. supra note 22, at 13.

'2s See supra text accompanying note 144 . 
istence or lack of interagency agreement, and many other elements can be weighed against each other on a sliding scale. If applied, this model will result in judicial judgments supported by more revealing reasons for deferring to agency decisions. Professor Merrill's model preserves the checks and balances necessary for a smoothly-functioning democratic government.

Required disclosure of changes in agency positions that result from executive oversight can enhance both agency and administrative accountability for regulatory decision-making. Such disclosure can be accomplished through legislative action. ${ }^{176}$ Finally, explicit policy guidance from Congress would also help clarify existing ambiguities in the Clean Water Act. Without a response of some kind, it is likely that current tension between economic and ecological interests under section 404 will continue unabated. The necessary result of inaction is continued wetlands loss and heightened dissatisfaction in the regulated community.

David M. Forman*

116 See supre note 151, for a list of bills submitted to the second session of the 102nd Congress to accomplish this goal.

- William S. Richardson School of Law, University of Hawaii, Class of 1992 1993. The author served as a legislative staff member for U.S. Senator John Breaux during the 1991 legislative session, while on a National Sea Grani Fellowship from the National Oceanic and Atmospheric Administration (NOAA). The views expressed in this article, however, are not necessarily intended to reflect the views of either Senator Breaux or the NOAA. 
